\title{
Social Media Marketing : A Critical Need for Business
}

\author{
Abhilasha Tiwari \\ Assistant Professor, Master of Business Administration, Rajarshi Rananjay Sinh Institute of Management \& \\ Technology, Amethi, Uttar Pradesh.
}

INTRODUCTION

In today's era pushed world Social media turns into an crucial conversation tool that human beings use to connect with different human beings or organization. People use social media to proportion their stories, reviews, statistics, advice, warnings, suggestions and/or any type of problems which are thrilling to their "connection" or pals. Social networking web sites have grow to be an street wherein stores can amplify their marketing campaigns to a much broader variety of purchasers. Chi $(2011,46)$ defines social media marketing as a "connection among manufacturers and purchasers, providing a non-public channel and foreign money for person focused networking and social interplay." The gear and procedures for speaking with clients have modified significantly with the emergence of social media; consequently, companies should discover ways to use social media in a manner this is steady with their enterprise plan (Mangold and Faulds 2099). This is mainly authentic for organizations striving to advantage a aggressive gain. This paper examines present day literature that specializes in a store's improvement and use of social media as an extension in their marketing approach. This phenomenon has handiest evolved withinside the final decade, therefore social media research has in large part targeted on (1) defining what it is thru the rationale of recent terminology and ideas that make-up its foundations, and (2) exploring the effect of a corporation's integration of social media on client conduct. This paper starts with an evidence of terminology that defines social media marketing, accompanied via way of means of a dialogue of the 4 foremost issues determined inside present day research research: Virtual Brand Communities, Consumers Attitudes and Motives, User Generated Content, and Viral Marketing.

Although social media marketing is a nicely-researched subject matter, it has handiest been studied via experimental and theoretical research; research by no means exactly describe the blessings stores advantage from this marketing tactic. In reviewing the wealthy plethora of multi-disciplinary literature, it's miles has grow to be clean that research are that specialize in describing what social media marketing is in addition to analysing what elements have an effect on client conduct relative to social networking. Despite the preliminary development made via way of means of researchers, improvement on this place of have a take a observe has been limited. Research wishes to extend via way of means of supplying a deeper expertise of the long- time period promotional profits stores reap from social media marketing. More formalized research also are had to development past theorized or expected results with a purpose to advantage information of actual-existence packages. This evaluation of literature touches upon the gaps that presently exist inside social media marketing research and factors out the want for destiny research to discover the blessings received via way of means of marketing on social networking web sites, mainly for small stores.

\section{DEFINING SOCIAL MEDIA}

To take into account social media as a marketing tool a store should recognize each issue of it. Social media can't be understood without first defining Web 2.zero: a time period that describes a brand new manner wherein quit customers use the World Wide Web, an area wherein content material is constantly altered via way of means of all operators in a sharing and collaborative manner (Kaplan and Haenlein 2010). "It is an awful lot greater to do with what human beings are doing with the era than the era itself, for in preference to simply retrieving statistics, customers at the moment are developing and ingesting it, and subsequently including cost to the web sites that allow them to do so" (Campbell et al. 2011, 87). Web 2.zero has developed from easy statistics retrieval to interactivity, interoperability, and collaboration (Campbell et al. 2011). Kaplan and Haenlein $(2010,61)$ outline social media as "a collection of Internet primarily based totally packages that construct at the ideological and technological foundations of Web 2.zero, and permit the advent and trade of person generated content material." Sinclaire and Vogus $(2011,294)$ cite O'Reilly's (2005) definition: “social media is a huge time period that describes software program gear that create person generated content material that may be shared." However, there are a few fundamental capabilities essential for a internet site to satisfy the necessities as a social community internet site: the web website online should include person profiles, content material, a way that lets in customers to connect to every different and publish remarks on every different's pages, and be a part of digital 


\section{DOI: $10.17148 /$ IJARCCE.2021.101011}

businesses primarily based totally on not unusualplace pastimes along with style or politics. (Gross \& Acquisti, 2005; Ellison, Steinfield \& Lampe, 2007; Lenhart \& Madden, 2007; Winder, 2007; Boyd \& Ellison, 2007 as mentioned in Cox 2010).

The word social networking web sites' is regularly used interchangeably with social media.

However, social media is distinctive as it permits members to unite via way of means of producing non-public statistics profiles and alluring pals and co-workers to have get admission to to the ones profiles (Kaplan and Haenlein 2010, 63). Thus, social media is the surroundings wherein social networking takes region and has altered the manner wherein purchasers accumulate statistics and make shopping for decisions.

Consumers' Sentiment in the direction of Marketing (CSM) is a component take into account via way of means of researchers to degree how nicely purchasers will understand social media marketing. CSM is described as a idea which refers to the overall emotions that purchasers have for marketing and the market (Lawson et al. 2001as mentioned via way of means of Mady 2011). An person's belief of the general market performs a main position in whether or not or now no longer they're encouraged to partake in intake activities (Mady 2011). In order to create a a success marketing marketing campaign thru social media, a client should be open to the era. Consumer era readiness is described as "human beings's propensity to include and use new technology for undertaking desires in domestic and work" (Parasuraman, 2000 as mentioned via way of means of Mady 2011, 195). Consumer era readiness is crucial for stores to keep in mind while marketing on social networks due to the fact if their supposed goal marketplace does now no longer use social media, isn't always acquainted with it, or perceives it negatively, then their social media marketing can be unrewarding. Analysis of era readiness can decide if marketing thru interactive advertising could be a very good healthy for a store's goal marketplace.

The Innovation Adoption Process (IAP) is some other tool that offers statistics on a client's recognition of recent era. The IAP is the development via which an person is going via the innovation-choice method (Rogers as mentioned in Mady 2011). Five steps make up the method: information of the innovation, forming an mindset in the direction of the innovation, finding out to undertake or reject the innovation, implementation of the innovation, and affirmation of the choice (Mady 2011). Knowledge of IAP can assist entrepreneurs reap a social media marketing marketing campaign this is fulfilling.

Social media has superior from absolutely supplying a platform for people to live in contact with their own circle of relatives and pals. Now it's miles an area wherein purchasers can study greater approximately their favourite organizations and the goods they sell. Marketers and stores are making use of those web sites as some other manner to attain purchasers and offer a brand new manner to save. "Technology associated tendencies along with the upward thrust of effective seek engines, superior cell gadgets and interfaces, peer-to-peer conversation vehicles, and on line social networks have prolonged entrepreneurs' cap potential to attain consumers via new contact factors" (Shankar et al. 2011, 30).

Shopper marketing is a brand new idea that has emerged, developing a brand new contact factor for the interactions among companies and purchasers. Shopper marketing is "the making plans and execution of all marketing activities that have an effect on a consumer alongside, and past, the complete course of buy, from the factor at which the inducement to save first emerges via buy, intake, repurchase, and recommendation" (Shankar et al. 2011, 29). Perceived healthy is an crucial component for stores to take into account for consumer marketing; perceived healthy is the quantity of similarity among an extension product class and present merchandise affiliated with the emblem (DelVecchio and Smith as mentioned in Cha 2009). The greater human beings understand purchasing offerings on social networking web sites as beneficial and clean to apply, the much more likely they're inclined to buy objects on social networks (Cha 2009). Providing purchasing offerings on social networks can offer enterprise boom for stores because of the variety of purchasers who use social media web sites. The extensive variety of purchasers making use of social networks method that maximum goal markets may be reached (Cha 2009). This affords an powerful platform for stores to sell their emblem and merchandise to cappotential purchasers. According to Shankar et al. (2011), consumer marketing can be a part of forces with consumers to enhance merchandise, create clean messages, discover promoters, and function a connection to in-keep activities, therefore demonstrating the significance of social media inside a store's marketing plan. Advancements inside social media web sites have created client groups which are defining new approaches wherein organizations and clients can have interaction with each other to proportion statistics on emblem merchandise. For instance, digital emblem groups are developing a computer-generated area for purchasers and stores to connect to each other thru marketing.

\section{VIRTUAL BRAND COMMUNITY}

A foremost subject matter being studied regarding social media as a marketing tool is Virtual Brand Communities (VBC). "VBC may be defined as aggregations of purchasers that arise at the net due to their hobby in a few emblem or product" (Muniz and O'Guinn as mentioned in Georgi and Mink 2012, 3). Specifically, a emblem network is a collection of individuals who proportion the equal hobby in a specific emblem or product (Casaló, Favián and Guinalíu 2008). Overall, VBC's are "the web website online[s] of complicated emblem that means advent and intake efforts" (Muñiz and Jensen Schau, 2007). Casaló, Favián and Guinalíu (2008) determined while a member is trusting of the VBC that they're a part 


\section{DOI: $\quad$ 10.17148/IJARCCE.2021.101011}

of, it will increase their quantity of participation, and purchasers who've a high-quality participation enjoy are greater dependable to the emblem. Trust is a relevant issue to assure the VBC's survival. Cha (2009) concludes that safety is a main component affecting a client's critiques in the direction of social networking web sites and might in the long run effect believe. Since VBCs rely on person customers' participation, each organization cohesion and attention can make stronger customers' pride with a VBC (Casaló, Favián and Guinalíu 2008). The have a take a observe completed via way of means of Casaló, Favián and Guinalíu (2008) demonstrates the effective sway VBC and an internet interplay among purchasers will have on their shopping for conduct.

Research additionally determined that inside those VBCs many new varieties of social interactions are taking region along with Electronic Consumer to Consumer Interaction (eCCI), which might be interactions among purchasers of e-offerings (Georgi and Mink 2012). The threat to mingle with different human beings is a essential a part of the client enjoy and social networking web sites have grow to be a manner wherein purchasers can have interaction with each other and stores (Georgi and Mink 2012). Because of eCCI, purchasers are gambling a greater dominant position in influencing every different with their intake decisions. Georgi and Mink (2012) got here up with the idea of digital client to client interplay pleasant (eCCIq). They determined that seven elements make a contribution to the fulfillment of eCCIq. These consist of content material, safety, hedonic (that means the emotional components of purchasers' interactions with merchandise), pleasant, atmosphere, convenience, and social. An instance of eCCI (that's any interplay among purchasers of e-offerings) is while a client posts a query approximately the healthy or shadeation of a product displayed on line and some other client solutions the query. This eCCI occasion could possibly be of excessive pleasant if the query is replied via way of means of some other client quick, correctly, and in a pleasant manner. This instance of an interplay among purchasers includes a number of the elements related to eCCIq along with social and convenience, therefore making it an eCCIq occurrence. Consumers sense greater engaged with merchandise and organizations once they have the choice to put up feedback (Mangold and Faulds 2009). Accordingly, it's miles crucial for stores to be aware about the pleasant in their social media presence even if purchasers are the creators in their marketing due to the fact it's miles an increasing number of influencing how purchasers save. Companies want to be aware about the range of things that have an effect on their social media presence along with a client's social identification on line.

Based at the research version, Pookulangara and Koesler (2011) finish that tradition does in truth have an effect on how people act and understand an occasion on era primarily based totally packages, along with social media. This method that an person's cultural or ethnic history will have an effect on how they may interpret social media and its content material. "Social networking has allowed the evolution of recent tradition wherein it's miles not formed via way of means of simply person values and ideologies, however additionally via way of means of new rituals and conversation gear withinside the social area of Web 2.zero" (Pookulangara and Koesler 2011, 352). Retailers want to take heed to the significance of tradition while making use of social media, on account that social networks are a merging of various cultures and the advent of recent on line cultures (Pookulangara and Koesler 2011). In addition, cultural backgrounds and traditions might also additionally component into the method of a client's opinion and mindset in the direction of a emblem or product.

\section{CONSUMER ATTITUDES/MOTIVES}

It is essential for stores and entrepreneurs to be aware about the elements that have an effect on client attitudes and reasons due to the fact purchasers are an increasing number of developing content material approximately manufacturers, some thing formerly managed completely via way of means of organizations (Heinonen 2011). As a result, present day research has tested what components of social media web sites have an effect on client attitudes and reasons. Chu (2011) tested the hyperlink among Facebook emblem associated organization participation, advertising responses, and the mental elements of self-disclosure and attitudes amongst members and nonmembers of Facebook businesses. The have a take a observe decided that customers who're members of businesses on Facebook are much more likely to reveal their nonpublic facts than nonmembers are. Chu (2011) explains organization participation and engagement with on line advertisements calls for a better degree of private statistics due to the fact customers overtly monitor their connections with Facebook businesses and sell manufacturers or merchandise once they byskip on advertisements to their pals. "Facebook businesses offer channels that purchasers deem beneficial while looking for self-fame in a product class, as does passing on viral content material approximately manufacturers to their social contacts" (Chu 2011, 40).

According to Chi (2011) customers understand advertising otherwise relying at the social community, which indicates person motivations for on line social networking might also additionally play a essential position in defining client's responses to social media marketing. As stated formerly withinside the rationalization of Pookulangara and Koesler's (2011) have a take a observe, the era recognition version (TAM) changed into additionally utilized by Harris and Dennis (2011). Harris and Dennis (2011), however, used TAM as a free framework that blended believe and the elements related to TAM (i.e. perceived entertainment, ease of use, and usefulness). The TAM decided that purchasers, mainly students, maintain a hierarchy of believe while the use of social media along with Facebook.

Student's believe 'actual' pals, then Facebook pals, accompanied via way of means of professional blogs and unbiased evaluation web sites and finally celebrities and e-store web sites (Harris and Dennis 2011). 
Vol. 10, Issue 10, October 2021

\section{DOI: 10.17148/IJARCCE.2021.101011}

Di Pietro and Pantano (2012) performed similarly research the use of the TAM to figure that entertainment is the most important component that impacts purchasers to apply social networks as a platform for supporting of their shopping for decisions. They determined that the amusing furnished via way of means of Facebook, in addition to the possibility it affords customers to invite for recommendations in an clean and exciting manner, motivates people to pay greater interest to the goods promoted on Facebook. "Facebook promotes a client to client technique, exploited via way of means of purchasers to proportion stories and create a not unusualplace information on merchandise and offerings; at the different, it affords managers an immediate channel for speaking with customers via a enterprise to client technique" (Di Pietro and Pantano 2012, 20). Retailers can enhance their Facebook web page attraction via way of means of including games, contests, and interactive packages, that can appeal to greater customers (Di Pietro and Pantano 2012).

However, stores additionally want to be knowledgeable on client's attitudes on the subject of social media marketing. A deeper expertise of the way purchasers understand social marketing will assist make certain marketing techniques are powerful.

Consumer activities of intake, participation, and manufacturing aren't associated with simply one motivation consistent with Heinonen (2011), who concluded that client activities are a aggregate of quite a few motivations. The conventional belief of people as mere purchasers is outdated; purchasers can now be visible as lively manufacturers of enterprise cost due to the fact person generated content material is decreasing the have an effect on of conventional marketing procedures (Heinonen 2011). Awareness of client's reasons is crucial as it affords a deeper expertise of what impacts customers to create content material approximately a emblem or keep.

\section{USER GENERATED CONTENT}

"While social media affords by no means finishing avenues for speaking, it's miles the people who function the influencers now no longer the era" (Gonzalez 2010, 23). User generated content material produces social foreign money for entrepreneurs as it allows outline a emblem. User generated content material describes "the sum of all approaches wherein human beings employ social media, commonly carried out to explain the numerous varieties of media content material which are publicly to be had and created via way of means of quit customers" (Kaplan and Haenlein 2010, 61). Therefore, social foreign money is while people proportion a emblem or statistics approximately a emblem (Zinnbauer and Honer 2011). Social foreign money significantly impacts emblem overall performance and is a idea that may be connected to Bourdieu's (1977) and Coleman's (1988) concept of social capital. Social capital is formed on a non-public degree and takes place withinside the relationships amongst people (Zinnbauer and Honer 2011).

Furthermore, the quantity of a person's social capital relies upon on the dimensions of the community of connections that the person can efficaciously mobilize (Bourdieu as mentioned in Zinnbauer and Honer 2011). An person's connections can doubtlessly useful resource in growing manufacturers into an critical a part of clients' social interactions thru social networking. "Translating [Bourdieu's] principle into today's world of exponentially an increasing number of social interactions at the net, social foreign money also can be understood as the whole thing of real and cappotential sources to be had to a emblem from its presence in social networks and groups" (Zinnbauer and Honer 2011, 51). There are six additives of social foreign money: affiliation, conversation, utility, advocacy, statistics, and indemnity (Zinnbauer and Honer 2011). Social currencies come from interactions among purchasers and are commonly past the direct manipulate of a company (Zinnbauer and Honer 2011). Through their empirical have a take a observe, Zinnbauer and Honer (2011) set up that even though social foreign money includes six distinctive additives, manufacturers do now no longer depend upon they all to facilitate emblem loyalty amongst customers. It changed into found however, that what made a emblem a success changed into being an critical a part of human beings's day by day lives. When a emblem turns into incorporated right into a client's day by day existence, it permits purchasers to connect, have interaction, and advantage from likeminded emblem customers, and therefore, the chance of client generated advertising for a emblem growth (Zinnbauer and Honer 2011).

Consumer Generated Marketing (CGA) is a shape of person-generated content material, which refers to precise times wherein purchasers create the emblem, targeted messages with the reason of informing, persuading, or reminding others (Campbell et al. 2011). Muñiz and Jensen Schau (2007) and Pehlivan, Sarican, and Berthon (2011) use the time period vigilante marketing to explain CGA. Vigilante marketing is described as "unpaid advertising and marketing efforts, which includes one to one, one to many, and plenty of to many commercially orientated communications, undertaken via way of means of emblem loyalists on behalf of the emblem" (Muñiz and Jensen Schau 2007, 35). Campbell et al. (2011) country that today, conventional marketing is coexisting with CGA. Retailers want to be aware about this due to the fact CGA can definitely assist conventional marketing or it could negatively effect and undermine it. Cheong and Morrison's (2010) research helps the preceding assertion via way of means of explaining how the shortage of research at the credibility of each high-quality and terrible person generated content material (UGC) highlights the want for stores to be aware and have a take a observe UGC to absolutely recognize its have an effect on. Consumers are taking element in a various array of activities along with ingesting content material, taking part in discussions, and sharing information with different purchasers, to contributing to different purchasers' activities (Heinonen 2011). 


\section{International Journal of Advanced Research in Computer and Communication Engineering}

Vol. 10, Issue 10, October 2021

\section{DOI: $10.17148 /$ IJARCCE.2021.101011}

Pehlivan, Sarican, and Berthon (2011) selected a grounded principle technique to evaluate CGA with Firm Generated Marketing (FGA), mainly for the massive famous Apple Corporation. They determined that CGA differs from FGA due to the fact every sort of advert (CGA or FGA) elicits distinctive dialogue content material surrounding the advert. Consumers explicit appreciation for FGA, however determined CGA to be greater exciting inflicting purchasers to speak approximately the advert greater (Pehlivan, Sarican, and Berthon 2011). Cheong and Morrison's 2008 have a take a observe have been comparable; they tested the distinction among UGC and manufacturer generated content material (PGC), which refers to content material created via way of means of entrepreneurs of merchandise, via way of means of interviewing university students. Overall, the have a take a observe determined that purchasers maintain greater believe in product statistics created via way of means of different purchasers than statistics generated from manufactures. Consumers' examine different purchasers' critiques to lower their dangers and reap pre-buy statistics; consequently, different purchasers' statistics emerges as greater crucial than advertising, therefore, people who publish UGC grow to be opinion leaders (Cheong and Morrison 2008). Another have a take a observe that focused on CGA changed into performed via way of means of Taylor, Strutton, and Thompson (2012); just like the fore point out research, their research shows that purchasers believe CGA over advertisements produced via way of means of organizations and the greater exciting the advert the greater it is going to be exceeded on.

Taylor, Strutton, and Thompson (2012), determined however, that social media customers' message sharing behaviors also are attributed to the want for self-enhancement. When purchasers understand an internet commercial to be steady with their identification, they're much more likely to proportion the message with others due to the fact it's miles consultant of who they're and what they like. Thus, "advertisers must take into account the symbolic and selfexpression houses in their on line advertisements and suit them to focused purchasers' self-concepts" (Taylor, Strutton, and Thompson 2012, thirteen). In different words, the marketing of a corporation wishes to proportion comparable traits with its goal marketplace's hobby. All of the findings from those research display the importance of CGA and its effect on on line marketing.

Viral advertising is a manner wherein manufacturers have become a essential a part of social media. As increasingly more purchasers' appearance to Facebook businesses as depended on reasserts of statistics and critiques, new possibilities get up to construct client-emblem relationships and viral advertising platforms (Chu 2011).

\section{VIRAL ADVERTISING}

Viral advertising has grown to be a manner wherein stores are marketing and supplying greater statistics on their manufacturers or merchandise. A viral technique to on line advertising has a main gain due to the fact conversation is greater focused to a emblem's supposed client (Bampo et al., 2008). This may be attributed to the truth that "viral conversation gives the marketer a more diploma of innovative license via a message transport medium this is greater intimate and personalized, thereby growing the chance of achieving tough to get target target market members" (Bampo et al. 2008, 274). Viral advertising is "unpaid peer to see conversation of provocative content material originating from an diagnosed sponsor the use of the Internet to influence or have an effect on an target target market to byskip alongside the content material to others" (Porter and Golan as mentioned via way of means of Chu 2011, 31). Viral advertising differs from UGC due to the fact an diagnosed sponsor is related to the advert, therefore signifying the beginning of the advert and who created it. Numerous research of viral advertising have determined that humor, sexuality, stealth, and high-quality stories are applicable elements that make a contribution to the fulfillment of viral advertising.

Kelly et al. (2010) decided that 3 elements influencing advert avoidance on line: interruption of task, perceived muddle at the Internet web sites, and terrible beyond stories with Internet advertising. "Research indicates the believability of trustworthiness of the medium impacts how the client perspectives the credibility of the statistics offered" (Moore and Rodgers as mentioned in Kelly et al. 2010, 17). Based in this have a take a observe, the bulk of advertisements featured on social networking web sites aren't applicable to purchasers, and that they handiest word advertisements while it annoys or entertains them. It has grow to be clean that classified ads that offer amusement are commonly appreciated and generic which reconfirms the outcomes of a few preceding research.

Because social media affords a brand new degree for emblem marketing and purchasers are actively contributing to the conversation via way of means of marketing manufacturers, companies have grow to be innovative while seeking to advantage manipulate in their marketing (Chi 2011). Tactics along with viral stealth marketing defined as "a marketer's try and fly underneath client radar via way of means of recruiting emblem pushers to pose as purchasers" has grow to be a brand new manner wherein entrepreneurs are seeking to manipulate social foreign money (Kaitkati and Kaikati as mentioned in Golan and Zaidner 2008, 961). When organizations use viral stealth marketing, they try and advantage foreign money withinside the shape of client to client guidelines, which might be argued because the most powerful of all client activities (Kaitkati and Kaikati as mentioned in Golan and Zaidner 2008). Viral stealth marketing techniques are designed to encourage client-to-client conversation approximately a emblem or product. Consumer to client conversation is the dominate pressure for dispensing messages created via way of means of advertisers; for that cause, stores want to have a take a observe marketing in an entire new manner and consist of social media marketing inside their enterprise plan (Golan and Zaidner 2008). 
International Journal of Advanced Research in Computer and Communication Engineering

Vol. 10, Issue 10, October 2021

\section{DOI: $10.17148 /$ IJARCCE.2021.101011}

Ultimately, the position of the client has modified and it's miles crucial to degree how purchasers have interaction with on line advertisements with a purpose to create a success social media marketing campaigns.

\section{CONCLUSION AND SUGGESTIONS FOR FURTHER RESEARCH}

In conclusion, research has decided that stores can growth attention in their emblem via way of means of being innovative while attractive clients on social media web sites. "As greater consumers are the use of social media (e.g., Twitter, Facebook, MySpace, and LinkedIn) and depend upon them for marketing purchasing decisions, promoting via those media has grow to be crucial" (Shankar et al. 2011,32). According to Curran et al. (2011), social media web sites along with Facebook are higher than different advertising avenues as it shops statistics on all its customers therefore making sure marketing reaches a store's precise goal marketplace. Social media web sites are a extraordinary degree for stores to create an enjoy and stores can use statistics saved on social media web sites to enhance person enjoy with their emblem.

Sorescue et al. (2011), pressure that a store should pass past the advertising issue of social networking web sites and locate groundbreaking approaches to apply them as a manner to behavior conversations with purchasers, rather than a one-manner conversation community. Sinclair and Vogus (2011) decided that massive organizations are concerning social media web sites as strategic gear and a few companies are even hiring personnel to supervise their social media pages. "Consumers are not passive receivers of marketing messages; instead, they're the use of Facebook, MySpace, YouTube, and Twitter to voice their critiques-each high-quality and terrible" (Sinclair and Vogus 2011,293). Consumers' participation with a emblem on social media reinforces the want for stores to be lively members in social networking web sites and the digital emblem groups they create.

Since social media web sites may be exploited for the statistics it affords on client conduct almost about their buying intentions, research similarly indicates that companies must contain social networking web sites into their enterprise version or promotional blend. A enterprise version is a machine of codependent structures, activities, and strategies that function a company's organizing good judgment and create cost for clients, itself, and its partners (Sorescu et al. 2011). Mangold and Faulds (2009) advise that social media must be seemed as an crucial a part of an organization's incorporated marketing approach and must now no longer be taken lightly. As Curran et al. (2011) factors out, nearly 1 in each thirteen folks withinside the world is an lively Facebook person, which factors to the cappotential of locating a equipped marketplace for any product or service.

Social networking web sites are being applied to beautify a corporation's emblem attraction and growth their goal marketplace due to the fact "new technology permit for greater non-public, focused communications, in addition to multiplied client participation withinside the advent of marketing and emblem associated statistics" (Cappo 2033; Jaffe 2005 as mentioned in Muñiz and Jensen Schau 2007, 35). Mangold and Faulds (2009) pressure that conventional conversation examples, which depended on the conventional promotional blend to create incorporated marketing communications, should provide manner to a brand new paradigm that consists of all varieties of social media as cappotential gear in designing and imposing incorporated marketing conversation techniques. Retailers are paying interest on the subject of social media as it affords a key element that companies have struggled to accumulate for years: feedback (Gonzalez 2010). Feedback from purchasers has usually been crucial on the subject of product, emblem, and enterprise version improvement. Since, maximum research have tested social media marketing in phrases of suggesting a way to contain it inside a enterprise plan, and a way to gauge purchasers' responses, it's miles crucial that similarly research deal with which techniques work. Although a few research have began out to comment on impacts and elements that have an effect on purchasers' responses, preceding research does now no longer absolutely country if social media marketing is treasured to stores' in phrases of go back on funding. Moreover, research primarily based totally on a small store's angle is limited. How have smaller corporations applied social media inside their enterprise version? How a success has social media been with growing their client base, emblem attention, and sales? It has grow to be clean that after entrepreneurs from massive organizations gift a brand new product or emblem, they take into account each conventional and nontraditional media wherein to region advertising with a purpose to make certain they attain their goal marketplace (Cheong and Morrison 2008). Small stores additionally want to begin making use of nontraditional techniques of marketing in innovative and attractive approaches to make sure that they appeal to a bigger variety of purchasers. Sorescu et al. $(2011,11)$ states "some other manner wherein stores can interact clients is via way of means of promoting now no longer simply merchandise, however a whole enjoy that - at the same time as focused on the goods, provides a wholly new thrilling layer to the retail setting."

Additional research is warranted concerning which social media marketing procedures are powerful for small stores. Further research should look at each the high-quality and terrible long- time period outcomes of social media marketing on a small company. Small stores have a smaller finances and tighter constraints but offer greater non-public retailing, consequently a have a take a observe analyzing how those components component right into a small keep's social media procedures could be beneficial. Research must additionally propose how small retail companies should provoke and keep social media marketing to enhance relationships with their client base. To live applicable stores, want to preserve up with the modifications to make certain that they may be observed via way of means of purchasers, reinforcing the truth that greater research could be treasured to all events concerned: stores, entrepreneurs, and scholars. 


\section{International Journal of Advanced Research in Computer and Communication Engineering}

Vol. 10, Issue 10, October 2021

DOI: $10.17148 /$ IJARCCE.2021.101011

“Anyone who's now no longer engaged in a few shape of social media is [making] a mistake in today's world given the quantity of human beings [who have] embraced and make use of social media" (Le Veque as mentioned in Gonzalez 2010, 84). Social media opens up an entire new world for small stores via way of means of supplying an countless array of cappotential interactions with purchasers, that's the primary cause why there may be a want for an growth in research analyzing the effect of this new phenomenon on small stores.

\section{REFERENCES:}

Bampo, Mauro, Michael T. Ewing, Dineli R. Mather, David Stewart, and Mark Wallace. 2008. "The Effects of the Social Structure of Digital Networks on Viral Marketing Performance.” Information Systems Research 19: 273-290.

Bourlakis, Michael, Savvas Papagiannidis, and Feng Li. 2009. "Retail Spatial Evolution: paving the way from traditional to metaverse retailing." Electronic Consumer Research 9:135-148.

Campbell, Colin, Leyland F. Pitt, Michael Parent, and Pierre R. Berthon. 2011. "Understanding Consumer Conversations around Ads in a Web 2.0 World." Journal of Advertising 40:87-102.

Cha, Jiyoung. 2009. "Shopping on Social Networking Websites: Attitudes towards real versus virtual items." Journal of Interactive Advertising, 10: 77-93.

Cheong, Hyuk Jun, and Margaret A. Morrison. 2008. “Consumers' Reliance on Product Information and Recommendations Found in UGC.” Journal of Interactive Advertising 8: 38-49.

Chi, Hsu-Hsien. 2011. "Interactive Digital Advertising VS. Virtual Brand Community: Exploratory Study of User Motivation and Social Media Marketing Responses in Taiwan.” Journal of Interactive Advertising 12: 44-61.

Cox, Shirley A. 2010. "Online Social Network Member Attitude Toward Online Advertising Formats." MA thesis, The Rochester Institute of Technology.

Chu, Shu-Chuan. 2011. "Viral advertising in social media: Participation in Facebook groups and responses among college-aged users." Journal of Interactive Advertising 12: 30-43.

Curran, Kevin, Sarah Graham, and Christopher Temple. 2011. “Advertising on Facebook.” International Journal of E-Business Development 1: 26-33. Di Pietro, Loredana and Elenora Pantano. 2012. "An Empirical Investigation of Social Network Influence on Consumer Purchasing Decision: The Case of Facebook." Journal of Direct Data and Digital Marketing Practice 14: 18-29.

Ferguson, Rick. 2008. "Word of mouth and viral marketing: taking the temperature of the hottest trends in marketing." Journal of Consumer Marketing 25: $178-182$.

Gonzalez, Cuitlahuac. 2010. "Social Media Best Practices for Communication Professionals through the Lens of the Fashion Industry." MA thesis, The University of Southern California.

Harris, Lisa and Charles Dennis. 2011. "Engaging customers on Facebook: Challenges for e-retailers,"

Journal of Consumer Behavior 10: 338-346.

Hassanein, Khaled and Milena Head. 2005-6. "The Impact of Infusing Social Presence in the Web Interface: An Investigation across Product Types." Interactive Journal of Electronic Commerce 10: 31-55.

Heinonen, Kristina. 2011. "Consumer activity in social media: Managerial approaches to consumers' social media behavior.” Journal of Consumer Behavior 10: 356-364.

Hill, Shawndra, Foster Provost, and Chirs Volinsky. 2006. "Network Based Marketing: Identifying Likely Adaptors via Consumer Networks." Statistical Science 21: 256-276.

Kaplan, Andreas M. and Michael Haenlein. 2010. "Users of the World, Unite! The Challenges and Opportunities of Social Media." Business Horizons 53: 59-68.

Kelly, Louis, Gayle Kerr, and Judy Drennan. 2010. “Avoidance of Advertising in Social Networking Sites: The Teenage Perspective.” Journal of Interacting Advertising 10: 16-27.

Mady, Tarek T. 2011. "Sentiment toward marketing: Should we care about consumer alienation and readiness to use technology?.” Journal of Consumer Behavior 10: 192-204.

Mangold, Glynn W., and David J. Faulds. 2009. "Social Media: The New Hybrid Element of the Promotion Mix.” Business Horizons 52: 357-365.

Muñiz, Albert M. and Hope Jensen Schau. 2007. "Vigilante Marketing and Consumer Created Communications." Journal of Advertising 36: 35-50.

Pavlou, Paul A., and David W. Stewart. 2000 "Measuring the Effects and Effectiveness of Interaction Advertising: A Research Agenda." Journal of Interactive Advertising 1: 62-78.

Pookulangara, Sanjukta and Kristian Koesler. 2011. “Cultural Influence on Consumers' Usage of Social Networks and its’ Impact on Online Purchase Intentions." Journal of Retailing and Xonsumer Services 18: 348-354.

Shankar,Venkatesh, Jeffery Inman, Murali Mantrala, Eileen Kelley, and Ross Rizley. 2011. "Innovations in Shopper Marketing: Current Insights and Future Research Issues.” Journal of Retailing 1:s29-s42, doi:10.1016/j.jretai.2011.04.007.

Taylor, David G., David Strutton, and Kenneth Thompson. 2012. "Self-Enhancement as a Motivation for Sharing Online Advertising." Journal of Interactive Advertising 12:13-28.

Zinnbauer, Markus, and Tobias Honer. 2011. "How Brands can Create Social Currency- a Framework for Managing Brands in a New Era.” Marketing Review St. Gallen 28: 50-55. 